\title{
Community approach towards COVID-19 in Turkey: one month after the first confirmed case
}

\section{Türkiye'de COVID-19'a yönelik toplum yaklaşımı: ilk vaka görülduikten bir \\ ay sonra}

\begin{abstract}
Hülya ŞiRiN¹, Gamze KETREZ ${ }^{1}$, Ahmad Abed AHMADi ${ }^{1}$, Ahmet ARSLAN¹, Emre ALTUNEL'1, İbrahim Sefa GÜNEȘ ${ }^{1}$, Ebru SEÇiLMiș ${ }^{1}$, Seçil ÖZKAN², Metin HASDE ${ }^{1}$
\end{abstract}

\section{ABSTRACT}

Objective: During this time when the COVID-19 is rising in Turkey, assessing the knowledge, attitude and practices of the public about the COVID-19 will be useful in finding out whether the interventions to control the outbreak are effective and viable. Furthermore, such studies are needed to properly manage the outbreak process and cast light on future interventions. This study aims to assess the knowledge, attitude and practices of people in Turkey about the COVID-19.

Methods: A cross-sectional survey was implemented between 11 and 21 April 2020 using an online questionnaire. The survey was applied online, and social media platforms were used to reach out to the highest number of people who met the inclusion criteria (i.n., people aged 18 or older). The questionnaire consists of three parts (socio-demographic 40 questions, medical history, and knowledge, attitude, and practice section). Descriptive statistics and a comparison of participants' knowledge degrees about COVID-19 is tested using the Chi square test.

Results: A total number of 8505 participant were

\section{ÖZET}

Amaç: Yeni koronavirüs hastalığı için koruyucu önlemler hakkında toplumun bilgi tutum ve davranıșlarını değerlendirmek, salgın kontrolü için uygulanan müdahalelerin etkinlik ve uygulanabilirlik düzeyini saptamakta fayda sağlayacaktır. Ayrıca, bu konudaki çalıșmalar salgın sürecini yönetebilme ve yeni yapılacak müdahalelere ışık tutması açısından gereklidir. Bu nedenle çalıșmamızın amacı Türkiye'de yașayan bireylerin Yeni Koronavirüs Hastalığı hakkında bilgi, tutum ve davranışlarını saptamaktır.

Yöntem: Bu kesitsel çalıșma 11-21 Nisan 2020 tarihleri arasında bir çevrimiçi anketi 10 kullanılarak uygulanmıștır. Anket çevrimiçi olarak uygulandı ve dâhil edilme kriterlerini karșılayan en yüksek sayıda kişiye (örneğin, 18 yaș ve üstü) ulașmak için sosyal medya platformları kullanıldı. Anket formu sosyodemografik, sağıı özgeçmiş ve bilgi, tutum ve davranıș sorularını içeren üç bölümden olușmaktadır. Çalıșmanın tanımlayıcı sonuçları verilmiștir. Katılımcıların sosyodemografik özeliklerine göre bilgi, tutum ve davranıșlarının analizinde ki-kare testi kullanılmıștır.

Bulgular: Calıșmada toplam 8505 kiși katılmıștır.

'University of Health Sciences, Gülhane School of Medicine, Department of Public Health, Ankara

${ }^{2}$ Gazi University, School of Medicine, Department of Public Health, Ankara

İletişim / Corresponding Author : Hülya ŞíRiN

Gülhane Tıp Fakültesi, Halk Sağlığı AD. Emrah, Gülhane Cd., 06010 Keçiören Ankara - Türkiye

E-posta / E-mail : hulya.sirin@sbu.edu.tr

Geliş Tarihi / Received : 09.08.2020 Kabul Tarihi / Accepted : 06.12.2020

DOI ID : 10.5505/TurkHijyen.2020.87059

Șirin H, Ketrez G, Ahmadi AA, Arslan A, Altunel E, Güneș iS, Seçilmiș E, Özkan S, Hasde M. Community approach towards COVID-19 in Turkey: one month after the first confirmed case. Turk Hij Den Biyol Derg, 2020; 77(4): 381-398 
accepted for the study. $59.3 \%$ (5045) of respondents were women and $77.7 \%$ (6808) had a university degree or higher. $85.6 \%$ (7277) of the participants had a good level of knowledge about COVID-19. Over $90 \%$ of participants have answered the questions about the mode of transmission of the COVID-19, symptoms, risk groups, isolation, and treatment correctly. 55.2\% (4696) of respondents thought that the disease would be successfully taken under control in Turkey and $38.6 \%$ (3282) in the world eventually. $55.6 \%$ (4731) believed that the COVID-19 will not go away when the weather gets warmer. $35.1 \%$ (2983) believed that getting the disease is preordained by fate. The most frequently practiced protective behaviors included hand hygiene, staying at home and wearing mask outside. $98.8 \%$ reported that they use their hands in order to protect theirselves from COVID-19.

Conclusion: Though, the knowledge attitude and practice of participants in our study was evaluated high, there were some knowledge and practice gaps in study population that should be considered in further community interventions. The future interventions for the epidemic control need to consider social determinants such as the level of education, employment status and religious beliefs of people.

Key Words: COVID-19, pandemic, knowledge, attitude, behavior
Katılımcıların \%59,3'ü (5045) kadın ve \%77,7'si (6808) üniversite veya üstü seviyede eğitim düzeyine sahipti. Katılımcıların \%90'ından fazlası hastalığın bulașma yolu, belirtileri, risk grupları, izolasyon ve tedavisi ile ilgili soruları doğru yanıtlamıștır. Katılımcıların \%55,2'si hastalığın Türkiye'de ve \%38,6'sı ise dünyada bașarıyla kontrol altına alınacağını düșünmektedir. Katılımcıların \%55,6'sı Yeni Koronavirüs enfeksiyonunun hava ısınınca sona ermeyeceğini ve $\% 35,1$ 'i hastalanmanın kaderi olduğunu düșünmektedir. Korunmaya yönelik davranıșlardan en çok uygulananları el hijyeni, evde kalma, dıșarıda maske takmadır. Katılımcıların \%98,8'i hastalıktan korunmak için ellerini yıkıyormuş.

Sonuç: Çalıșmamız kapsamındaki kișilerin bilgi tutumu ve davranışları yüksek olarak değerlendirilmiș olsa da, çalıșma popülasyonunda daha sonraki toplum müdahalelerinde dikkate alınması gereken bazı bilgi ve davranış boșlukları belirlenmiștir. Gelecekte olabilecek salgın kontrolü müdahalelerinde, insanların eğitim seviyesi, istihdam durumu ve dini inançları gibi sosyal belirleyicilerde dikkate alınmalıdır.

Anahtar Kelimeler: COVID-19, pandemi, bilgi, tutum, davranıș

\section{INTRODUCTION}

The novel coronavirus disease (COVID-19) was first defined when unexplained pneumonia cases occurred among people who worked and shopped at a seafood market in Wuhan, China, in December 2019 (1). Epidemiological studies on the disease suggested that the disease extended beyond people who consumed seafood. Therefore, people were led to think that there was evidence of human-tohuman transmission $(2,3)$. The latest studies indicate transmission through droplets or direct contact (4).

The disease then went on to spread rapidly in other countries. On 30 January 2020, WHO declared a "public health emergency of international concern". On 11 March 2020, WHO announced the disease as a pandemic (5).

The disease symptoms often include fever, dry cough, shortness of breath, muscle soreness, 
weakness, headache, chest pain, and diarrhea. Severe cases are also characterized by respiratory failure, renal failure, septic shock, and multi-organ failure (6-8). It was reported that the clinical course of the disease was more severe among people with underlying chronic illnesses (e.g., hypertension, diabetes, respiratory diseases, cardiovascular diseases, cancer, etc.) and the elderly $(6,9)$. Yet, it is also known that some people tested positive for COVID-19 are asymptomatic (10-12).

As COVID-19 is a communicable disease, preventive measures including wearing masks, hand hygiene, staying away from crowded areas, and social distancing are significant in the prevention and outbreak control (13).

Contacts of patients identified through contact tracing are quarantined for 14 days, which is the disease's incubation period (14).

Similar to other countries, Turkey took a number of measures, including the shutdown of schools followed by distance education, canceling all meetings, closure of houses of worship, curfew on people aged $\geq 65$ and under 20, and obligatory use of masks in public areas in order to curb the spread of the disease. The first case was detected in Turkey on 11 March 2020. This was followed by further awareness-raising interventions such as developing and airing public spots and the use of billboards (15).

During this time, when the COVID-19 is rising in Turkey, assessing the public's knowledge, attitude, and practices about the COVID-19 will be useful in finding out whether the interventions to control the outbreak are effective and viable. There are no prior studies conducted in Turkey on the assessment of knowledge, attitude, and practices. Yet, such studies are needed to properly manage the outbreak process and cast light on future interventions.

Thus, this study aims to assess the knowledge, attitude, and practices of people in Turkey towards COVID-19.

\section{MATERIAL and METHOD}

\section{Study Population}

This was a descriptive survey. The survey was implemented between 11 and 21 April 2020, one month after the first case was confirmed in Turkey. The survey was applied online, and social media platforms were used to reach out to the highest number of people who met the inclusion criterion (i.e., people aged 18 or older). According to TURKSTAT (The Turkish Statistical Institute)-2020 results, the population aged 18 or older is 60278977 . The minimum sample size required was calculated as 9603 people within a 95\% confidence level using the Epilnfo computer programme (Centers for Disease Control and Prevention, Atlanta, USA), assuming anticipated frequency of $50.0 \%$ and absolute precision of $1.0 \%$. Respond rate was $89,9 \%$. The survey was approved by the Decision of the Ethical Committee of Gazi University.

\section{Questionnaire and Data Collection}

The questionnaire was developed after reviewing the literature, preventive strategies in Turkey, and frequently asked questions on reliable websites. Questionanarie language have taken as plain as possible in order to make the questions simple and easy to understand. The online questionnaire was designed using Google forms and pre-tested online on 15 people from different socio-demographic backgrounds before it was finalized. The online questionnaire was launched on Google forms on 11 April 2020, and data were collected for ten days. The survey link was shared with the public using social media (i.e., WhatsApp, Facebook, Instagram, and Twitter).

The survey included questions on participants' socio-demographic information, Medical history, knowledge, attitude, and practices towards COVID-19.

The socio-demographic section inquired about age, sex, civil status, education level, employment status, province of residence, whether there are individuals 
aged $\geq 65$ or under 20 in the household, the existence of any chronic disease and any other illness, and smoking status. The section on knowledge, attitude, and practices was included 20 questions: ten on knowledge, five on attitudes, and five on practices. The responses were designed as "True", "False" and "I Do not know" in the section on knowledge; "Yes", "No" and "I Do not know" in the section on attitudes, and "Do the right thing" and "Do not do the right thing" in the section on practices.

\section{Statistical Analysis}

Categorical variables were summarized with count and percent and compared using The ChiSquare Test. Responses to the question on occupation were grouped as "health worker" and "other", and answers to the question on the province of residence were grouped as "istanbul" (where nearly $2 / 3$ of the cases in Turkey occur) and "other". Regarding responses to practices, "I never go out" and "I go out for essential needs" were considered the right behavior for the question of staying at home. The response "Yes, I wear a mask whenever I go out" was considered proper for the question of using masks. As regards the questions for measuring the knowledge level, 1 point was given to each right answer marked "True" and 0 to incorrect answers marked "False" or "Do not know". The evaluation was based on 10 points in total. Afterward, the knowledge level of respondents was classified based on these scores (0-5: poor, 6-8: fair, and 9-10: good). A Chi-square test is used to analyze the knowledge, attitudes, and practices of respondents based on socio-demographic characteristics. All data management and statistical analysis of the study is done in SPSS 25.0 packages. A $p<0.05$ was considered statistically significant in all statistical analyses.

\section{RESULTS}

Eight thousand six hundred forty respondents completed the survey, of which 135 people who participated from abroad Turkey did not complete the survey properly were excluded, and 8505 participants were considered for final evaluation. People from all provinces of Turkey participated in the survey. Of total respondents; 59.3\% (5045) were woman, 38.9\% (3310) aged 36-50 years, 29.1\% (2471) aged 21-35 years, 68.4\% (5817) were married, 63.4\% (5393) were working, $77.7 \%$ (6808) had a university degree or higher, and $17.7 \%$ (1501) lived in i̇stanbul province. Participants' age groups, civil status, employment status, work arrangement, and the province of residence had significantly differed across gender $(\mathrm{p}<0.001)$ (Table 1).

The knowledge level of respondents about the COVID-19 was classified as "good","fair" and "poor". According to this classification, 85.6\% (7277) had a good level of knowledge.

The knowledge level of participants seemed to increase in proportion to their level of education $(p<0.001)$. The knowledge level was higher among married respondents compared to single participants $(p=0.003)$, and respondents currently employed are better informed than unemployed individuals $(p<0.001)$. Health workers had a higher level of knowledge than other professions $(p<0.001)$. Detailed comparison of participants' level of knowledge about COVID-19 according to their socio-demographic characteristics is shown in Table 2.

Over $90 \%$ of participants have answered the questions about the mode of transmission of the COVID-19, symptoms, risk groups, isolation, and treatment correctly. The percentage of correct response was the lowest in the questions about the vaccine $85.8 \%$ (7299) and transmission from pets to humans 78.3\% (6657) (Table 3).

$55.2 \%$ (4696) of respondents thought that the disease would be taken under control in Turkey, and $38.6 \%$ (3282) in the whole world eventually. $55.6 \%$ (4731) believed that the COVID-19 would not go away when the weather gets warmer. 35.1\% (2983) believed that getting the disease is preordained by fate (Table 4). 
Table 1. Socio-demographic Characteristics of Respondents by Sex

\begin{tabular}{|c|c|c|c|c|}
\hline Variable & Male n (\%) & Female n (\%) & Total n (\%) & $\mathrm{p}^{*}$ \\
\hline \multicolumn{5}{|l|}{ Age $(n=8505)$} \\
\hline$\leq 20$ & $113(3.3)$ & 198(3.9) & $311(3.7)$ & \multirow{5}{*}{$<0.001$} \\
\hline $21-35$ & $889(25.7)$ & $1582(31.4)$ & $2471(29.1)$ & \\
\hline $36-50$ & $1326(38.3)$ & $1984(39.3)$ & $3310(38.9)$ & \\
\hline $51-64$ & $1000(28.9)$ & $1164(23.1)$ & $2164(25.4)$ & \\
\hline $65 f$ & $1323(3.8)$ & $117(2.3)$ & $249(2.9)$ & \\
\hline \multicolumn{5}{|l|}{ Civil Status $(n=8505)$} \\
\hline Married & $2587(74.8)$ & $3230(64.0)$ & $5817(68.4)$ & \multirow{2}{*}{$<0.001$} \\
\hline Single & $873(25.2)$ & $1815(36.0)$ & $2688(31.6)$ & \\
\hline \multicolumn{5}{|l|}{ Education Status } \\
\hline Primary School & $189(5.5)$ & $289(5.7)$ & $478(5.6)$ & \multirow{3}{*}{0.308} \\
\hline Secondary School & $554(16.0)$ & $865(17.1)$ & 1419(16.7) & \\
\hline University and higher & $2717(78.5)$ & $3891(77.1)$ & $6608(77.7)$ & \\
\hline \multicolumn{5}{|c|}{ Employment Status $(n=8505)$} \\
\hline Employed & $2425(70.1)$ & $2968(58.8)$ & $5393(63.4)$ & \multirow{2}{*}{$<0.001$} \\
\hline Unemployed & 1035(29.9) & $2077(41.2)$ & $3112(36.6)$ & \\
\hline \multicolumn{5}{|c|}{ Work Arrangement $(n=5394)$} \\
\hline Goes to work every day & $923(38.0)$ & 614(20.7) & $1537(28.5)$ & \multirow{7}{*}{$<0.001$} \\
\hline Goes to work in shifts & $751(31.0)$ & $881(29.7)$ & $1632(30.3)$ & \\
\hline On paid leave & $204(8.4)$ & $386(13.0)$ & $590(10.9)$ & \\
\hline On unpaid leave & $93(3.8)$ & $155(5.2)$ & $248(4.6)$ & \\
\hline Works from home & $367(15.1)$ & $798(26.9)$ & $1165(21.6)$ & \\
\hline On medical leave & $66(2.7)$ & $108(3.6)$ & $174(3.2)$ & \\
\hline Other & $22(0.9)$ & $26(0.9)$ & $48(0.9)$ & \\
\hline \multicolumn{5}{|c|}{ Province of Residence $(n=8502)$} \\
\hline İstanbul & $481(13.9)$ & $1020(20.2)$ & 1501(17.7) & \multirow{2}{*}{$<0.001$} \\
\hline Other & $2978(86.1)$ & $4023(79.8)$ & $7001(82.3)$ & \\
\hline
\end{tabular}

\%: Column. Bold: The difference between categories was evaluated by corrected p-value (Bonferroni method), and bolded cells denote a subset of gender categories whose column proportions differ significantly from each other at the 0.05 level. ${ }^{*} \mathrm{p}$-value refers to the comparison of variables by sex. 
Table 2. Comparison of Knowledge Level of Respondents by Socio-demographic Characteristics $(n=8505)$

\begin{tabular}{|c|c|c|c|c|}
\hline Characteristics & Good n (\%) & Fair n (\%) & Poor n (\%) & $\mathrm{P}^{*}$ \\
\hline \multicolumn{5}{|l|}{ Sex } \\
\hline Men & $2963(85.6)$ & $470(13.6)$ & $27(0.8)$ & \multirow{2}{*}{0.476} \\
\hline Women & $4314(85.5)$ & $702(13.9)$ & $29(0.6)$ & \\
\hline \multicolumn{5}{|l|}{ Age } \\
\hline$\leq 20$ & $209(67.2)$ & $95(30.5)$ & $7(2.3)$ & \\
\hline $21-64$ & $6859(86.3)$ & 1044(13.1) & $42(0.5)$ & \\
\hline $65 f$ & $209(83.9)$ & $33(13.3)$ & $7(2.8)$ & \\
\hline \multicolumn{5}{|l|}{ Education Status } \\
\hline Primary School & $245(51.3)$ & $211(44.1)$ & $22(4.6)$ & \multirow{3}{*}{$<0.001$} \\
\hline Secondary School & $1040(73.3)$ & $362(25.5)$ & $17(1.2)$ & \\
\hline University and higher & 5992(90.7) & $599(9.1)$ & $17(0.3)$ & \\
\hline \multicolumn{5}{|l|}{ Civil status } \\
\hline Married & $5026(86.4)$ & $758(13.0)$ & $33(0.6)$ & \multirow{2}{*}{0.003} \\
\hline Single & $2251(83.7)$ & $414(15.4)$ & $23(0.9)$ & \\
\hline \multicolumn{5}{|l|}{ Employment Status } \\
\hline Employed & $4757(88.2)$ & $617(11.4)$ & $19(0.4)$ & \multirow{2}{*}{$<0.001$} \\
\hline Unemployed & $2520(81.0)$ & $555(17.8)$ & $37(1.2)$ & \\
\hline \multicolumn{5}{|l|}{ Profession } \\
\hline Health worker & $1586(92.9)$ & $120(7.0)$ & $2(0.1)$ & \multirow{2}{*}{$<0.001$} \\
\hline Profession & $5691(83.7)$ & 1052(15.5) & $54(0.8)$ & \\
\hline \multicolumn{5}{|l|}{ Province of residence } \\
\hline İstanbul & $1327(88.5)$ & $170(11.3)$ & $2(0.1)$ & \multirow{2}{*}{$<0.001$} \\
\hline Other & $5948(85.0)$ & $1001(14.3)$ & $49(0.7)$ & \\
\hline \multicolumn{5}{|l|}{ Smoking status } \\
\hline Yes & $1997(83.7)$ & $380(15.9)$ & $10(0.4)$ & \multirow{2}{*}{0.001} \\
\hline No & $5280(86.4)$ & 792(13.0) & $41(0.7)$ & \\
\hline \multicolumn{5}{|l|}{ Chronic disease } \\
\hline Yes & $1660(85.9)$ & $262(13.6)$ & $11(0.6)$ & \multirow{2}{*}{0.922} \\
\hline No & $5616(85.5)$ & 910(13.9) & $40(0.6)$ & \\
\hline \multicolumn{5}{|c|}{ Is there a household member aged 20 or younger? } \\
\hline Yes & $4026(84.2)$ & $720(15.1)$ & $35(0.7)$ & \multirow{2}{*}{$<0.001$} \\
\hline No & 3251 (87.5) & $450(12.1)$ & $16(0.4)$ & \\
\hline \multicolumn{5}{|c|}{ Is there a household member aged $\geq 65$ ? } \\
\hline Yes & 1183(84.1) & $210(14.9)$ & $14(1.0)$ & \multirow{2}{*}{0.039} \\
\hline No & $6094(85.9)$ & $960(13.5)$ & $37(0.5)$ & \\
\hline
\end{tabular}

\%: Row. *P-values indicate column total. Bold: The difference between categories was evaluated by corrected $\mathrm{p}$-value (Bonferroni method), and bolded cells denote a subset of row categories whose proportions differ significantly from each other at the 0.05 level. 
Table 3. Correct and Wrong Answers of Respondents to Questions about the COVID-19 ( $n=8505)$

\begin{tabular}{|c|c|c|}
\hline Variable & Correct answer $\mathrm{n}(\%)$ & Wrong answer $\mathrm{n}(\%)$ \\
\hline $\begin{array}{l}\text { The COVID- } 19 \text { is transmitted by inhaling the droplets from infected } \\
\text { persons when they cough or sneeze. }\end{array}$ & $8222(96.7)$ & $283(3.3)$ \\
\hline $\begin{array}{l}\text { You may contact the COVID-19 by touching contaminated surfaces and } \\
\text { then touching your face, eyes, nose, or mouth. }\end{array}$ & $8443(99.3)$ & $62(0.7)$ \\
\hline $\begin{array}{l}\text { The most common symptoms of the COVID-19 are fever, dry cough, and } \\
\text { shortness of breath. }\end{array}$ & $8449(99.3)$ & $56(0.7)$ \\
\hline $\begin{array}{l}\text { The COVID-19 has a higher risk of causing severe disease and death among } \\
\text { the elderly and persons with underlying diseases (e.g., asthma, diabetes, } \\
\text { cardiac disease). }\end{array}$ & $8432(99.1)$ & $73(0.9)$ \\
\hline $\begin{array}{l}\text { People infected with the COVID-19 do not infect others unless they have } \\
\text { symptoms such as fever, cough, etc. }\end{array}$ & $7697(90.5)$ & $808(9.5)$ \\
\hline $\begin{array}{l}\text { People who have contacted COVID-19 patients must be isolated in an } \\
\text { appropriate place for at least } 14 \text { days. }\end{array}$ & $8368(98.4)$ & $137(1.6)$ \\
\hline $\begin{array}{l}\text { Isolating and treating people infected with COVID-19 is an effective way } \\
\text { of reducing the spread of the virus. }\end{array}$ & $8363(98.3)$ & $142(1.7)$ \\
\hline There is a vaccine for the COVID-19 & $7299(85.8)$ & $1206(14.2)$ \\
\hline $\begin{array}{l}\text { Children and young adults do not need to take measures to protect from } \\
\text { the COVID-19 }\end{array}$ & 7768(91.3) & $737(8.7)$ \\
\hline The COVID-19 is transmitted from pets to humans. & $6657(78.3)$ & $1848(21.7)$ \\
\hline
\end{tabular}

$\%$ : Row

Table 4. Respondents' Attitudes about the COVID-19 ( $n=8505)$

\begin{tabular}{|l|c|c|c|}
\hline Variable & Yes $n(\%)^{*}$ & No $n(\%)^{*}$ & I Do not know n(\%)* \\
\hline $\begin{array}{l}\text { I think the COVID-19 will be successfully controlled in } \\
\text { Turkey }\end{array}$ & $4696(55.2)$ & $1782(21.0)$ & 2027(23.8) \\
\hline $\begin{array}{l}\text { I think the COVID-19 will be successfully controlled in the } \\
\text { whole world }\end{array}$ & $3282(38.6)$ & $2291(26.9)$ & 2932(34.5) \\
\hline $\begin{array}{l}\text { I think that the COVID-19 will go away when the weather } \\
\text { gets warmer }\end{array}$ & $1115(13.1)$ & $4731(55.6)$ & 2659(31.3) \\
\hline $\begin{array}{l}\text { I may get the COVID-19 no matter how many measures I } \\
\text { take if it is the call of fate }\end{array}$ & $2983(35.1)$ & $4002(47.1)$ & 1520(17.9) \\
\hline $\begin{array}{l}\text { I believe hand hygiene and hygiene, in general, are } \\
\text { essential in controlling the outbreak }\end{array}$ & $8450(99.4)$ & $20(0.2)$ & $35(0.4)$ \\
\hline
\end{tabular}

$\%$ : Row 
The difference in attitudes of respondents toward the COVID-19 was statistically significant when evaluated in terms of sex, age, education status, civil status, employment status, smoking status, province of residence, and presence of a household member aged $\geq 65$ or 20 years or younger $(p<0.001)$.

Men and people with primary education tended to believe in a higher percentage that the disease will be controlled in Turkey and worldwide eventually.
Respondents aged less than 65, respondents with low education levels, health workers, respondents living in other cities than İstanbul, and participants without chronic disease tend to have a stronger belief that getting the COVID-19 is the call of fate (Table 5).

The most commonly adopted practices to protect from the COVID-19 include hand hygiene (hand washing and using disinfectants), staying at home, and wearing masks outside (Figure 1).

Table 5. Respondents' Attitudes towards the COVID-19 by Certain Characteristics (\%)

\begin{tabular}{|c|c|c|c|c|c|}
\hline & $\begin{array}{l}\text { It will be } \\
\text { controlled in } \\
\text { Turkey } \\
\end{array}$ & $\begin{array}{l}\text { It will be } \\
\text { controlled } \\
\text { worldwide }\end{array}$ & $\begin{array}{l}\text { It will go away } \\
\text { when the weather } \\
\text { gets warmer }\end{array}$ & $\begin{array}{l}\text { I believe getting } \\
\text { the disease is } \\
\text { the call of fate }\end{array}$ & $\begin{array}{l}\text { Hygiene rules } \\
\text { are important }\end{array}$ \\
\hline \multicolumn{6}{|l|}{ Sex } \\
\hline Men & 58.5 & 43.6 & 13.2 & 34.8 & 99.3 \\
\hline Women & 53.0 & 35.2 & 13.0 & 35.3 & 99.4 \\
\hline $\mathrm{p}^{*}$ & $<0.001$ & $<0.001$ & 0.774 & 0.626 & 0.863 \\
\hline \multicolumn{6}{|l|}{ Age } \\
\hline$\leq 20$ & 56.6 & 38.3 & 16.7 & 37.6 & 98.1 \\
\hline $21-64$ & 55.5 & 38.5 & 13.0 & 35.5 & 99.4 \\
\hline $65 f$ & 43.0 & 40.6 & 11.2 & 17.3 & 98.8 \\
\hline $\mathrm{p}^{*}$ & 0.003 & 0.806 & 0.113 & $<0.001$ & - \\
\hline \multicolumn{6}{|l|}{ Education Status } \\
\hline Primary School & 72.6 & 45.4 & 24.3 & 52.5 & 96.4 \\
\hline Secondary School & 59.5 & 40.8 & 16.0 & 39.5 & 99.1 \\
\hline University and higher & 53.0 & 37.6 & 11.7 & 32.9 & 99.6 \\
\hline $\mathrm{p}^{*}$ & $<0.001$ & 0.001 & $<0.001$ & $<0.001$ & $<0.001$ \\
\hline \multicolumn{6}{|l|}{ Civil status } \\
\hline Married & 57.6 & 39.4 & 13.9 & 35.2 & 99.5 \\
\hline Single & 50.0 & 36.9 & 11.5 & 34.7 & 99.1 \\
\hline $\mathrm{p}^{*}$ & $<0.001$ & 0.030 & 0.003 & 0.633 & 0.054 \\
\hline \multicolumn{6}{|l|}{ Employment Status } \\
\hline Employed & 56.8 & 38.6 & 12.6 & 36.0 & 99.6 \\
\hline Unemployed & 52.5 & 38.5 & 14.0 & 33.5 & 99.0 \\
\hline $\mathrm{p}^{*}$ & $<0.001$ & 0.930 & 0.053 & 0.022 & 0.002 \\
\hline
\end{tabular}


Table 5 (cont.). Respondents' Attitudes towards the COVID-19 by Certain Characteristics (\%)

\begin{tabular}{|c|c|c|c|c|c|}
\hline & $\begin{array}{l}\text { It will be } \\
\text { controlled in } \\
\text { Turkey }\end{array}$ & $\begin{array}{l}\text { It will be } \\
\text { controlled } \\
\text { worldwide }\end{array}$ & $\begin{array}{l}\text { It will go away } \\
\text { when the weather } \\
\text { gets warmer }\end{array}$ & $\begin{array}{l}\text { I believe getting } \\
\text { the disease is } \\
\text { the call of fate }\end{array}$ & $\begin{array}{l}\text { Hygiene rules } \\
\text { are important }\end{array}$ \\
\hline \multicolumn{6}{|l|}{ Profession } \\
\hline Health worker & 53.6 & 34.6 & 13.8 & 38.4 & 99.8 \\
\hline Other Profession & 55.6 & 39.6 & 12.9 & 34.2 & 99.2 \\
\hline $\mathrm{p}^{*}$ & 0.310 & $<0.001$ & 0.374 & 0.001 & 0.007 \\
\hline \multicolumn{6}{|l|}{ Province of residence } \\
\hline İstanbul & 41.8 & 32.5 & 10.5 & 28.2 & 99.3 \\
\hline Other & 58.1 & 39.9 & 13.7 & 36.6 & 99.4 \\
\hline $\mathrm{p}^{*}$ & $<0.001$ & $<0.001$ & 0.001 & $<0.001$ & 0.918 \\
\hline \multicolumn{6}{|l|}{ Smoking status } \\
\hline Yes & 51.3 & 36.4 & 11.6 & 36.2 & 99.3 \\
\hline No & 56.8 & 39.5 & 13.7 & 34.7 & 99.4 \\
\hline $\mathrm{p}^{*}$ & $<0.001$ & 0.008 & 0.012 & 0.192 & 0.865 \\
\hline \multicolumn{6}{|l|}{ Chronic disease } \\
\hline Yes & 52.6 & 37.9 & 11.7 & 32.1 & 99.3 \\
\hline No & 56.0 & 38.8 & 13.5 & 35.9 & 99.4 \\
\hline $\mathrm{p}^{*}$ & 0.008 & 0.505 & 0.034 & 0.002 & 0.632 \\
\hline \multicolumn{6}{|c|}{ Is there a household member in the risky age group? } \\
\hline Both $\leq 20$ and $\geq 65$ & 55.5 & 39.9 & 14.1 & 37.0 & 99.5 \\
\hline $\begin{array}{l}\text { One of the above } \\
\text { risky age group }\end{array}$ & 57.9 & 38.6 & 13.9 & 37.8 & 99.4 \\
\hline $\begin{array}{l}\text { No household member } \\
\text { in at-risk age group }\end{array}$ & 50.4 & 38.2 & 11.5 & 30.0 & 99.3 \\
\hline $\mathrm{p}^{*}$ & $<0.001$ & 0.756 & 0.007 & $<0.001$ & 0.776 \\
\hline
\end{tabular}

\%: Row. *P-values indicate column total. Bold: The difference between categories are evaluated by corrected p-value (Bonferroni method), and bolded cells denote a subset of row categories whose proportions differ significantly from each other at the 0.05 level. 
Using contactless credit card

\section{Using mask outside \\ Staying at home \\ Using hand disinfectant \\ Washing hands}

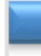

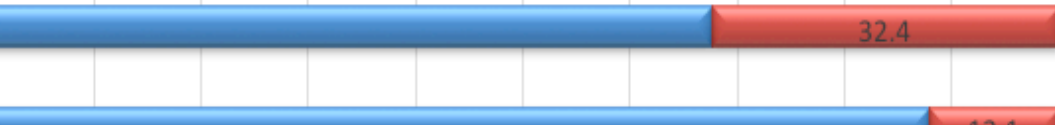

\section{준}

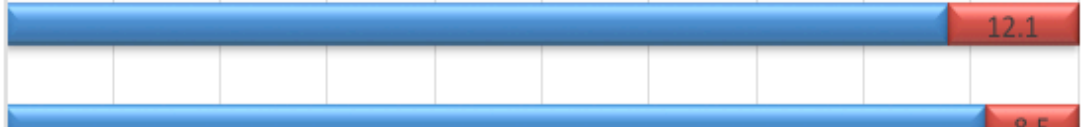

\section{.}

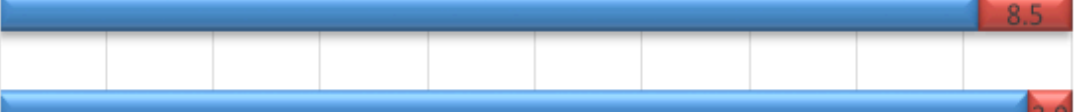

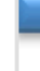

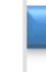

20

40

70
90 100

\section{$\boldsymbol{\nabla}$ Yes $\boldsymbol{\Delta}_{\mathrm{N}}$}

Figure 1. Percentage Distribution of Practices of Respondents about Measures against the COVID-19 ( $=8505)$

The difference in practices of respondents was found to be statistically significant when evaluated in terms of sex, age, education status, civil status, employment status, smoking status, province of residence, and presence of a household member aged $\geq 65$ or 20 years or younger $(p<0.05)$.

Female respondents stayed at home more $(p<0.001)$; the rate of wearing masks $(p<0.001)$ was also higher among them, and they washed their hands more $(p=0.026)$ than male participants.

From the perspective of age groups, respondents aged $\leq 20$ and $\geq 65$ stayed at home more, and those aged 21-64 and $\geq 65$ years wearied masks more than other participants $(p<0.001)$. From the perspective of education status, the tendency to use masks outside was higher among university graduates than the primary school graduates $(\mathrm{p}=0.002)$, and using contactless credit cards were practiced lower among people with primary school level of education $(p<0.001)$. Single respondents stay at home more than married participants $(p<0.001)$. On the other hand, the use of masks $(p<0.001)$, hand washing $(p<0.001)$, use of contactless credit cards $(p<0.001)$, and using hand disinfectants $(\mathrm{p}=0.033)$ were more common among married respondents. Respondents that do not work were more attentive to staying at home and using masks outside $(p<0.001)$ compared to participants that work, and the respondents that work use contactless credit cards and hand disinfectants $(p<0.001)$ more than those who do not work. From the perspective of professions, respondents who are not health workers stay at home more $(p<0.001)$, but the use of masks and contactless credit cards $(p<0.001)$ is higher among health workers. Residents of istanbul stay at home $(p<0.003)$ and use contactless credit cards more $(p<0.001)$. Non-smokers stay at home use masks outside $(p<0.001)$ and contactless credit cards more than smokers $(p=0.016)$. Respondents with chronic illnesses were more attentive to using masks than those without any chronic disease $(p<0.001)$. The use of contactless credit cards is lower among respondents with a household member aged $\leq 20$ and $\geq 65$ years $(p=0.002)$ (Table 6$)$. 
Table 6. Adopting the Right Practices about the COVID-19 by Certain Characteristics (\%)

\begin{tabular}{|c|c|c|c|c|c|}
\hline & $\begin{array}{l}\text { Staying at } \\
\text { home }\end{array}$ & $\begin{array}{l}\text { Wearing masks } \\
\text { outside }\end{array}$ & $\begin{array}{l}\text { Washing } \\
\text { hands }\end{array}$ & $\begin{array}{l}\text { Using contactless } \\
\text { credit cards }\end{array}$ & $\begin{array}{l}\text { Using Hand } \\
\text { Disinfectant }\end{array}$ \\
\hline \multicolumn{6}{|l|}{ Sex } \\
\hline Men & 88.5 & 82.5 & 98.5 & 68.4 & 96.1 \\
\hline Women & 93.5 & 91.5 & 99.0 & 67.0 & 96.1 \\
\hline$p^{*}$ & $<0.001$ & $<0.001$ & 0.026 & 0.180 & 0.867 \\
\hline \multicolumn{6}{|l|}{ Age } \\
\hline Aged 20 years and younger & 98.7 & 81.4 & 95.5 & 62.1 & 95.5 \\
\hline Aged 21-65 & 91.0 & 88.0 & 98.9 & 67.8 & 96.1 \\
\hline Aged $\geq 65$ & 98.4 & 91.2 & 98.8 & 66.3 & 97.2 \\
\hline $\mathrm{p}^{*}$ & $<0.001$ & $<0.001$ & $<0.001$ & 0.094 & 0.579 \\
\hline \multicolumn{6}{|l|}{ Education Status } \\
\hline Primary School & 92.7 & 83.9 & 96.7 & 49.6 & 94.4 \\
\hline Secondary School & 90.8 & 88.1 & 98.6 & 62.4 & 96.1 \\
\hline University and higher & 91.5 & 88.1 & 99.0 & 70.0 & 96.2 \\
\hline$p^{*}$ & 0.835 & 0.002 & $<0.001$ & $<0.001$ & 0.127 \\
\hline \multicolumn{6}{|l|}{ Civil status } \\
\hline Married & 90.9 & 89.1 & 99.1 & 69.4 & 96.4 \\
\hline Single & 92.6 & 85.2 & 98.2 & 63.7 & 95.4 \\
\hline$p^{*}$ & 0.013 & $<0.001$ & 0.001 & $<0.001$ & 0.033 \\
\hline \multicolumn{6}{|l|}{ Employment Status } \\
\hline Employed & 87.1 & 87.2 & 99.0 & 69.0 & 96.7 \\
\hline Unemployed & 98.9 & 88.9 & 98.6 & 65.1 & 95.1 \\
\hline $\mathrm{p}^{*}$ & $<0.001$ & $<0.001$ & 0.095 & $<0.001$ & $<0.001$ \\
\hline \multicolumn{6}{|l|}{ Profession } \\
\hline Health worker & 81.3 & 91.1 & 99.2 & 74.7 & 96.8 \\
\hline Profession & 94.0 & 87.0 & 98.7 & 65.8 & 95.9 \\
\hline$p^{*}$ & $<0.001$ & $<0.001$ & 0.069 & $<0.001$ & 0.098 \\
\hline \multicolumn{6}{|l|}{ Province of residence } \\
\hline İstanbul & 93.4 & 89.7 & 99.1 & 72.9 & 96.0 \\
\hline Other & 91.0 & 87.5 & 98.8 & 66.4 & 96.1 \\
\hline$p^{*}$ & 0.003 & 0.058 & 0.315 & $<0.001$ & 0.859 \\
\hline \multicolumn{6}{|l|}{ Smoking status } \\
\hline Yes & 88.8 & 85.5 & 98.7 & 65.6 & 95.9 \\
\hline No & 92.5 & 88.8 & 98.8 & 68.3 & 96.2 \\
\hline $\mathrm{p}^{*}$ & $<0.001$ & $<0.001$ & 0.713 & 0.016 & 0.491 \\
\hline
\end{tabular}


Table 6 (cont.). Adopting the Right Practices about the COVID-19 by Certain Characteristics (\%)

\begin{tabular}{|c|c|c|c|c|c|}
\hline & $\begin{array}{l}\text { Staying at } \\
\text { home }\end{array}$ & $\begin{array}{l}\text { Wearing masks } \\
\text { outside }\end{array}$ & $\begin{array}{l}\text { Washing } \\
\text { hands }\end{array}$ & $\begin{array}{l}\text { Using } \\
\text { contactless } \\
\text { credit cards }\end{array}$ & $\begin{array}{l}\text { Using Hand } \\
\text { Disinfectant }\end{array}$ \\
\hline \multicolumn{6}{|l|}{ Chronic disease } \\
\hline Yes & 92.2 & 91.8 & 98.9 & 69.0 & 96.3 \\
\hline No & 91.2 & 86.7 & 98.8 & 67.1 & 96.0 \\
\hline $\mathrm{p}^{*}$ & 0.182 & $<0.001$ & 0.636 & 0.112 & 0.615 \\
\hline \multicolumn{6}{|c|}{ Is there a household member in the risky age group? } \\
\hline $\begin{array}{l}\text { Is there a household member } \\
\text { aged } 20 \text { or younger? }\end{array}$ & 90.7 & 87.7 & 98.7 & 66.5 & 95.6 \\
\hline $\begin{array}{l}\text { Is there a household member } \\
\text { aged } \geq 65 \text { ? }\end{array}$ & 92.3 & 89.9 & 98.9 & 65.3 & 97.4 \\
\hline $\begin{array}{l}\text { Are there household members } \\
\text { aged } 20 \text { years and younger and } \\
\geq 65 \text { ? }\end{array}$ & 88.9 & 88.8 & 98.6 & 62.0 & 96.9 \\
\hline $\begin{array}{l}\text { No household member in the } \\
\text { at-risk age group }\end{array}$ & 91.8 & 87.2 & 99.0 & 69.3 & 96.4 \\
\hline $\mathrm{P}^{*}$ & 0.072 & 0.636 & 0.630 & 0.002 & 0.182 \\
\hline
\end{tabular}

\%: Row. *P-values indicate column total. Bold: The difference between categories is evaluated by corrected $\mathrm{p}$-value (Bonferroni method), and bolded cells denote a subset of row categories whose column proportions differ significantly from each other at the 0.05 level.

\section{DISCUSSION}

The female-male ratio in our study was higher. The employment status also reflected the general situation in the country; the number of employed men was higher than that of female participants (16). Likewise, smoking prevalence was higher among men than women, consistent with the data from the Turkish Tobacco Atlas (17). The overall education level of the respondents was higher than the Turkey average. This was most likely because the survey was conducted online, and respondents had to use smartphones and computers.

More than $90 \%$ of the respondents correctly answered 8 of the knowledge questions. The researchers also think that the increasing number of epidemiological studies and the emergence of reliable information from December to the day (that this study started) helped to raise the knowledge level of the public in the country. Another critical factor is that this study was conducted one month after the pandemic announcement and the first case in Turkey. Similarly, a survey in the Netherlands showed an increase in knowledge levels in time (18).

$90.5 \%$ of the participants correctly answered the question "People infected with the novel coronavirus do not infect others unless they have symptoms such as fever cough, etc." and $91.3 \%$ correctly answered the statement "Children and young adults do not need to take measures to protect from the COVID-19". The rates of the correct response to these questions in a similar study in the US were $79.3 \%$ and $84.9 \%$, 
respectively (19). Besides other reasons, the overall high level of education seems to explain the high knowledge level among respondents. Because the knowledge level increases in proportion to the level of education, this was the case in a study in Egypt, too (21). There was no statistically significant difference between the sexes in our study, even though many studies in the literature suggest a higher knowledge level among female participants $(20,22)$.

Moreover, the difference between health workers and other professions was not statistically significant in responding to the questions on "the symptoms of the disease and isolation of contacts." Health workers were relatively well informed about it because Turkey engaged in extensive public information activities in the period of one month from the first confirmed case until the time of our survey. One could suggest that the Ministry of Health in particular and local administrations, CSOs, professional organizations, and the media generally increased efforts to raise public awareness in the said period of time.

The rate of the correct response to the knowledge statements "There is a vaccine for the COVID-19" and "The COVID-19 is transmitted from pets to humans" was below $90 \%$. The possible reason for this is that information about the vaccine and transmissibility of pets is still somewhat unclear.

$55.2 \%$ of respondents thought that the disease would be taken under control in Turkey, and 38.6\% believed it would eventually be controlled worldwide. This rate was higher in a Chinese study (20). The likely reason for this is that WHO had not announced the disease a pandemic back then, and people mostly believed that its spread would remain limited. In our study, respondents with higher education status believed that the pandemic would not be taken under control.

Fatalism is known to be associated with a lack of measures and taking risks. A high level of fatalism reduces efforts for having information and taking measures among patients of cancer and similar diseases and increases risk-taking among adolescents $(23,24)$. Fatalism was included as an aspect of our survey because fatalistic attitudes in Turkey are an essential factor in health. In our study, the fatalistic attitude was significantly higher among female respondents. Similarly, a study among university students found that fatalistic attitudes were considerably higher among female students (25). This leads one to think that women have more fatalistic tendencies in general.

Although they are optimistic in general, the respondents do not think the disease will disappear when the weather gets warmer. This is possible because there are COVID-19 cases in warm climates, including African countries (26). In contrast, health workers have a stronger belief that the disease will go away when the weather gets warmer, and they display more fatalistic attitudes.

Again, non-smokers were more optimistic than smokers that the disease will be taken under control, and it will disappear when the weather gets warmer. Smokers and respondents with chronic illnesses seemed to be more worried. Married respondents and participants with someone aged 20 or younger in the household were more hopeful.

The tendency to believe that getting the disease is the call of fate and that the disease will be controlled in Turkey and worldwide gets lower as the education level increases. On the other hand, the importance attached to hygiene increases parallel to the level of education. The fact that the majority of respondents think hand hygiene and hygiene, in general, are important in outbreak control is consistent with the results of a Hong Kong study on avian influenza, where the majority of participants thought active personal hygiene measures reduced the flu risk (27). A knowledge and attitude survey of health workers in Vietnam found that the majority of respondents correctly believed that washing hands is effective in preventing transmission (28).

In our study, the most commonly practiced 
preventive measure was "handwashing". A study in Turkey indicates that $61.6 \%$ of the population wash their hands more than ten times a day. Moreover, $78 \%$ believe that washing hands is very important in preventing diseases (29). The fact that $99 \%$ of the respondents in our survey thought that hand washing is important indicates that washing hands is indeed the most crucial measure in protecting from the disease. This also shows the importance and effectiveness of public awareness to throw media and other channels. In our survey, "using contactless credit cards" ranked the lowest among the inquired protective measures. This is possible because contactless credit cards are not commonly used in Turkey.

$87.9 \%$ of the respondents wear masks. This rate is lower compared to some countries (98\%) and higher when compared to others $(24 \%)(19,20)$. The researchers also think that using masks could be affected by sociocultural differences in the countries and time of a given survey. Because mask use became widespread and mandatory in different countries at different times, another potential factor is the difficulty of getting masks. Furthermore, the US study was conducted before the recommendations of the WHO and CDC about mask use. The survey in Turkey was conducted after wearing masks became mandatory in Turkey. This could explain the difference between the surveys. Initially, masks were recommended for patients and contacts alone. Today, however, people are urged to wear masks in public areas $(30,31)$. CDC has recently recommended that cloth masks could be used to cover the face (32). The US study was conducted on 17 March. 19 However, the Turkish Ministry of Interior announced mandatory use of masks when visiting marketplaces, grocery stores, and public workplaces on 3 April 2020, and our study was conducted on 11-21 2020. The researchers believe that this rule affected public behavior and the responses to the survey (33).

The rate of staying home was higher among respondents aged 20 or younger and $\geq 65$ as both groups were already subject to a curfew by the time our survey was collecting data. In addition, attention to other practices (including using masks, washing hands, and using hand disinfectants etc) increases in older respondents.

This is consistent with our study: women, older respondents, and participants with higher education levels better observe preventive practices. Crosssectional studies on SARS in Singapore and Hong Kong suggested similar results $(34,35)$. However, no association was found between these factors and preventive methods in the Dutch study (36).

Similar to the literature, our survey found lower compliance with measures among smokers compared to non-smokers (37). Smoking is an overall risk for health, and it is expected to be a risk factor for the COVID-19.

Compliance with the measures was higher among respondents with chronic illnesses than those without any chronic condition. This was particularly true for using masks. The researchers think that an underlying chronic disease raises concerns and sensitivity, resulting in better compliance with preventive measures. A study in Canada suggested that respondents who feel more at risk of SARS took more measures. This is consistent with our study (38).

\section{LIMITATIONS}

Given the extraordinary circumstances of the pandemic, the survey conducted online through social media platforms as the possibility of a national sampling survey using face-to-face interviews was precluded due to the measures and the social distancing rule in the country. This result may have been obtained due to the higher education and health literacy levels of the participants compared to the general population. In addition, the number of female participants in our study is higher than that of men, and they are weak in representing the general population. 


\section{CONCLUSION}

In times of public health threats such as pandemics, the prudence, strategies, and interventions of countries have a substantial effect on the knowledge, attitudes, and practices of the population. In Turkey, the first case was detected later than in other countries, and this was helpful in using the experience of others. The political measures were supported by intervention programs by the mass media in order to guide the knowledge, attitudes, and practices of the public.

Although our survey, which was conducted one month after the first case was confirmed, was limited to online media, it has nevertheless reached out to a significant number of respondents in the pandemic conditions. The findings of the survey suggest that the population is sufficiently informed about the COVID-19. This underlines the importance of informing people using mass media. The survey shows that this has been adequately done in the country. Mass media is crucial in raising the health literacy of the population, particularly in times of emergencies that threaten public health.

Our results suggest that interventions aiming to change the knowledge, attitude, and practices of the public should consider social determinants of health, including education level, employment status, and religious beliefs.

Besides knowledge, other positive factors include country-wide restrictions (curfew on holidays, curfew imposed on specific age groups, mandatory use of masks in public areas, etc.) and enabling interventions (distributing free masks, paid and unpaid leave for employees, etc.). Our study found a high level of compliance with the measure of staying at home. In times of public health threats, therefore, informing the population needs to be supported with enabling conditions and a number of mandatory practices.

As a result, it is necessary to repeat studies on knowledge, attitudes, and practices of the population regularly in times of pandemics in order to identify gaps and develop timely recommendations. 


\section{REFERENCES}

1. Li Q, Guan X, Wu P, Wang X, Zhou L, Tong $Y$, et al. Early transmission dynamics in Wuhan, China, of novel coronavirus-infected pneumonia. N Engl J Med, 2020;382(13):1199-207.

2. Chan JFW, Yuan S, Kok KH, To KKW, Chu H, Yang J, et al. A familial cluster of pneumonia associated with the 2019 novel coronavirus indicating personto-person transmission: a study of a family cluster. Lancet, 2020;395(10223):514-23.

3. Kang M, Wu J, Ma W, He J, Lu J, Liu T, et al. Humanto-human transmission of 2019-novel coronavirus (2019-nCoV). medRxiv, 2020; published online Jan1. DOI:2020.02.03.20019141.

4. Modes of transmission of virus causing COVID-19: implications for IPC precaution recommendations. https://www.who.int/news-room/commentaries/ detail/modes-of-transmission-of-virus-causingcovid-19-implications-for-ipc-precautionrecommendations (accessed May 6,2020).

5. World Health Organization (WHO). Novel coronavirus (2019-nCoV). Situation report. https:// www. who.int/docs/default-source/coronaviruse/ situation-reports/20200207-sitrep-18-ncov. pdf?sfvrsn=fa644293_2 (accessed May 6,2020).

6. Wang D, Hu B, Hu C, Zhu F, Liu X, Zhang J, et al. Clinical Characteristics of 138 Hospitalized Patients With 2019 Novel Coronavirus-Infected Pneumonia in Wuhan, China. JAMA, 2020;323(11):1061-9.

7. Huang C, Wang Y, Li X, Ren L, Zhao J, Hu Y, et al. Clinical features of patients infected with 2019 novel coronavirus in Wuhan, China. Lancet, 2020;395(10223):497-506.

8. Chen N, Zhou M, Dong X, Qu J, Gong F, Han Y, et al. Epidemiological and clinical characteristics of 99 cases of 2019 novel coronavirus pneumonia in Wuhan, China: a descriptive study. Lancet, 2020;395(10223):507-13.
9. Zhou F, Yu T, Du R, Fan G, Liu Y, Liu Z, et al. Clinical course and risk factors for mortality of adult inpatients with COVID-19 in Wuhan, China: a retrospective cohort study. Lancet, 2020;395(10229):1054-62.

10. Bai $Y$, Yao L, Wei T, Tian F, Jin D-Y, Chen L, et al. Presumed Asymptomatic Carrier Transmission of COVID-19. JAMA, 2020;323(14):1406-7.

11. Lai CC, Liu YH, Wang CY, Wang YH, Hsueh SC, Yen MY, et al. Asymptomatic carrier state, acute respiratory disease, and pneumonia due to severe acute respiratory syndrome coronavirus 2 (SARSCoV-2): Facts and myths. J Microbiol Immunol Infect, 2020; published online Mar 4. https://doi. org/10.1016/j.jmii.2020.02.012.

12. Rothe C, Schunk M, Sothmann P, Bretzel G, Froeschl G, Wallrauch C, et al. Transmission of 2019NCOV infection from an asymptomatic contact in Germany. N Engl J Med, 2020;382(10):970-1.

13. CDC. Coronavirus Disease 2019 (COVID-19), How to Protect Yourself \&Others. 2020. https://www.cdc. gov/coronavirus/2019-ncov/prevent-getting-sick/ prevention.html (accessed May 7,2020).

14. Turkish Ministry of Health. COVID-19 (SARS-Cov-2 Infection) Guide, Scientific Committee. 2020. https://covid19bilgi.saglik.gov.tr/depo/rehberler/ COVID-19_Rehberi.pdf (accessed May 5, 2020).

15. Turkish Ministry of Health. 14 Rules to Counter the Novel Coronavirus Risk, 2020. https://covid19bilgi. saglik.gov.tr/depo/afisler/Halk/COVID-19_14_ KURAL_AFIS_50X70.pdf (accessed May 6, 2020).

16. Türkiye İstatistik Kurumu. İstatistiklerle Kadın, 2019. http://www.tuik.gov.tr/PreHaberBultenleri. do?id=33732 (accessed May 2,2020).

17. The Tobacco Atlas, Turkey, 2015. https:// tobaccoatlas.org/country/turkey/ (accessed May 2,2020). 
18. Bults M, Beaujean DJMA, de Zwart O, Kok G, van Empelen $\mathrm{P}$, van Steenbergen JE, et al. Perceived risk, anxiety, and behavioural responses of the general public during the early phase of the Influenza A (H1N1) pandemic in the Netherlands: results of three consecutive online surveys. BMC Public Health, 2011;11(1):2.

19. Clements JM. Knowledge and behaviors toward COVID-19 among U.S. residents during the early days of the pandemic. medRxiv, 2020; published online April 2. https://doi. org/10.1101/2020.03.31.20048967 (preprint).

20. Zhong B-L, Luo W, Li H-M, Zhang Q-Q, Liu X-G, Li $W-T$, et al. Knowledge, attitudes, and practices towards COVID-19 among Chinese residents during the rapid rise period of the COVID-19 outbreak: a quick online cross-sectional survey. Int J Biol Sci, 2020;16(10):1745-52.

21. Abdelhafiz AS, Mohammed Z, Ibrahim ME, Ziady HH, Alorabi M, Ayyad M, et al. Knowledge, Perceptions, and Attitude of Egyptians Towards the Novel Coronavirus Disease (COVID-19). J Community Health, 2020. https://doi.org/10.1007/s10900020-00827-7.

22. ALdowyan N, Abdallah AS, El-Gharabawy R. Knowledge, Attitude and Practice (KAP) Study about Middle East Respiratory Syndrome Coronavirus (MERS-CoV) among Population in Saudi Arabia. Int Arch Med, 2017;10 (254):1-12.

23. Ramírez AS. Fatalism and Cancer Risk Knowledge Among a Sample of Highly Acculturated Latinas. J Cancer Educ, 2014;29(1):50-5.

24. Haynie DL, Soller B, Williams K. Anticipating early fatality: friends', schoolmates' and individual perceptions of fatality on adolescent risk behaviors. J Youth Adolesc, 2013;43(2):175-92.

25. Kaya A, Bozkur B. Kadercilik Eğilimi İle Özyeterlik İnancı ve Savunma Mekanizmaları Arasındaki İlișkinin İncelenmesi. Ege Eğitim Derg, 2017;18(1):124-45
26. Euronews. Covid-19 salgını sıcak kıta Afrika'da 46 ülkeye yayıldı, virüs Avrupa'dan geldi, 2020. https: / / tr.euronews.com/2020/03/30/covid-19salg-n-s-cak-k-ta-afrika-da-46-ulkeye-yay-ld-virusavrupa-dan-geldi (accessed May 5, 2020).

27. Chan EYY, Cheng CKY, Tam G, Huang Z, Lee P. Knowledge, attitudes, and practices of Hong Kong population towards human A/H7N9 influenza pandemic preparedness, China, 2014. BMC Public Health, 2015;15(1):943.

28. Giao H, Le An P, Thi Ngoc Han N, Van Khanh T, Kim Ngan V, Van Tam V. Knowledge and attitude toward COVID-19 among healthcare workers at District 2 Hospital, Ho Chi Minh City. Asian Pac J Trop Med, 2020;13(March):6-11

29. Turkish Ministry of Health. Survey on Hand Washing in Turkey, Ankara, 2012. https://sbu.saglik.gov.tr/ Ekutuphane/kitaplar/elyika_tr.pdf (accessed May 3, 2020).

30. Critically Important Antimicrobials For Human Medicine. Geneva: World Health Organization. 6th ed. 2018. https://apps.who.int/iris/bitstream/ha ndle/10665/312266/9789241515528-eng.pdf, Date Accessed: 07.06.2017

31. HASUDER Yeni Koronavirüs (COVID-19) Haber Postası (06.04.2020) - Yeni Koronavirüs Hastalığı 2019. https://korona.hasuder.org.tr/hasuder-yenikoronavirus-covid-19-haber-postasi-06-04-2020/ (accessed May 4, 2020)

32. CDC. Recommendation Regarding the Use of Cloth Face Coverings, Especially in Areas of Significant Community-Based Transmission, 2020. https:// www.cdc.gov/coronavirus/2019-ncov/preventgetting-sick/cloth-face-cover.html (accessed May 4,2020).

33. Turkish Ministry of Interior. Şehir Giriș/Çıkış Tebirleri ve Yaș Sınırlaması, 2020. https://www. icisleri.gov.tr/sehir-giriscikis-tebirleri-ve-yassinirlamasi (accessed May 3,2020). 
34. Quah SR, Hin-Peng L. Crisis prevention and management during SARS outbreak, Singapore. Emerg Infect Dis, 2004;10(2):364-8.

35. Lau JTF, Yang $\mathrm{X}$, Tsui $\mathrm{H}$, Kim JH. Monitoring community responses to the SARS epidemic in Hong Kong: From day 10 to day 62. J Epidemiol Community Health, 2003;57(11):864-70.

36. Rugarabamu S, Byanaku A, Ibrahim M. Knowledge, attitudes, and practices (KAP) towards COVID-19: A quick online cross-sectional survey among Tanzanian residents. medRxiv, 2020; published online May 1. https://doi.org/10.1101/2020.04.2 6.20080820 .
37. Tyas SL, Pederson LL. Psychosocial factors related to adolescent smoking: A critical review of the literature. Tob Control, 1998;7(4):409-20.

38. Maunder R, Hunter J, Vincent L, Bennett J, Peladeau $\mathrm{N}$, Leszcz M, et al. The immediate psychological and occupational impact of the 2003 SARS outbreak in a teaching hospital. Cmaj, 2003;168(10):1245-51. 